\title{
Assessing the distribution and abundance of larval Longfin Smelt: What can a larval monitoring program tell us about the distribution of a rare species?
}

\author{
MICHAEL EAKIN ${ }^{1}$ \\ Sacramento, CA 95605, USA \\ *Corresponding Author: michael.eakin@wildlife.ca.gov
}

${ }^{1}$ California Department of Fish and Wildlife, Water Branch, 1010 Riverside Parkway, West

Following its listing as threatened under the California Endangered Species Act in 2009, Longfin Smelt (Spirinchus thaleichthys) became a focus of resource managers in the San Francisco Estuary. Water exports were identified as one of the factors affecting Longfin Smelt abundance, and managers were challenged with balancing freshwater flows through the Sacramento-San Joaquin River Delta between human and ecosystem needs. This balance becomes especially challenging during the winter and spring when Longfin Smelt are spawning. Resource managers identified that the impact associated with entrainment of larval Longfin Smelt in the winter was uncertain, and to understand and manage this risk, new data was needed. In 2009 the Smelt Larva Survey was implemented and has since sampled newly hatched larvae from January-March. Here, I analyze this data and ask specific questions regarding distribution and densities of the larvae throughout five regions of the Upper Estuary - Napa River, Suisun, Confluence, Northern Delta, and Southern Delta - with the goal of understanding the spatial and temporal patterns of larval distribution since 2009. I found that larvae were most prevalent in the Suisun, Confluence, and Northern Delta regions, and less common in the Southern Delta and Napa River regions. Larval Longfin Smelt densities changed following a recent drought and record low population abundances. Median per-station averaged densities ranged from 154 to 274 fish per $1,000 \mathrm{~m}^{3}$ between 2009 and 2013 but declined to 1 to 65 fish per $1,000 \mathrm{~m}^{3}$ from 2014 to 2019 . This survey data demonstrates that Longfin Smelt reproductive output has declined since their listing in 2009 and that their distribution into the Southern Delta is low relative to the rest of the Upper Estuary. These results reaffirm the species' continued decline since its listing, and that improving the abundance of spawning adults is one of the many important steps needed for long-term recovery and resilience.

Key words: California Endangered Species Act, larval fish, Longfin Smelt, San Francisco Estuary, smelt larva survey 
Longfin Smelt (Spirinchus thaleicthys) was once one of the most abundant fish species in the San Francisco Estuary (Estuary) (Rosenfield and Baxter 2007). This small, anadromous fish with a one-to-three-year lifespan, migrates into low salinity and freshwater habitats during the late fall and early winter to spawn (Baxter 1999; Merz et al. 2013; Moulton 1974). Longfin Smelt are generally mature and ready to spawn by age two (CDFG 2009a). Once hatched, most young of the year Longfin Smelt rear in the Upper Estuary in important nursery areas (Hobbs et al. 2006) prior to emigrating downstream into more saline habitats, where they stay until adulthood (Rosenfield and Baxter 2007). Over time, the species declined to record low levels in the Estuary, leading to its listing as Threatened under the California Endangered Species Act (CESA) in 2009 (CDFG 2009a). During the status review for the listing process, the California Department of Fish and Game [now the California Department of Fish and Wildlife (CDFW)] identified that one of the important factors affecting Longfin Smelt abundance was loss associated with water diversions, chiefly from the State Water Project (SWP) and the Central Valley Project (CVP), which are located in the southern extent of the Sacramento-San Joaquin River Delta (Delta) (CDFG 2009a).

The SWP is designed to export approximately 4.2 million acre-feet of water per year and deliver it south for agricultural, municipal, and industrial needs ${ }^{1}$. The Banks Pumping Plant is the main export facility for the SWP and is located approximately $12 \mathrm{~km}$ northwest of the town of Tracy, CA. The Banks Pumping Plant has a rated diversion capacity of 10,300 cfs and is the majority of the export capacity between the two facilities. Similarly, the Jones Pumping Plant is the key export facility for the CVP and exports an average of 5.6 million acre-feet of water for agricultural, municipal, and industrial needs ${ }^{2}$. The Jones Pumping Plant is located approximately $3 \mathrm{~km}$ east of the Banks Pumping Plant and has a rated diversion capacity of 5,200 cfs. Because of their combined export capacity and geographic location, the SWP and CVP have a substantial effect on how freshwater routes through the Delta, and specifically, can draw water south through Old and Middle rivers which are distributaries of the San Joaquin River (Monsen et al. 2007). The magnitude of southward Old and Middle river flows combined with the seasonal occurrence of Longfin Smelt was shown to be a predictor of entrainment, which is defined as the involuntary movement of fish into the water diversions at the SWP and CVP (Grimaldo et al. 2009).

To both understand and minimize loss of fish to water diversions, the SWP and CVP constructed fish salvage facilities to collect fish which would have otherwise been entrained into the diversion pumps (Morinaka 2013a; Reyes et al. 2018). These facilities are located a short distance upstream of each project's pumping plants. The fish salvage facilities utilize a series of behavioral barriers, which are referred to as louvers, to guide fish into a bypass system, rather than a positive barrier which is meant to exclude fish, such as a fish screen (Brown et al. 1996). Upon collection, fish are counted and identified before being transported by truck back to the Estuary and released. This process is referred to as "salvage" (Morinaka 2013b). Data collected from the fish salvage facilities has been important in understanding impacts to native fish species associated with freshwater diversions of the Delta (Kimmerer 2008). However, the salvage process was not designed to salvage larval fishes. This is due to the size bias of louvers and the salvage process itself. The louvers are most effective on fish that can swim against strong currents (Castillo et al. 2012) which means that small,

\footnotetext{
${ }^{1}$ https://water.ca.gov/Programs/State-Water-Project

${ }^{2}$ https://www.usbr.gov/mp/cvp/
} 
passively swimming larvae are unlikely to be diverted into the bypass system. Additionally, the louvers are most effective on fish larger than $30 \mathrm{~mm}$ fork length (Kimmerer 2008) and fish that are less than $20 \mathrm{~mm}$ fork length are not identified or counted within the salvage data (Morinaka 2013b). Because of this, a substantial data gap exsisted regarding entrainment and loss of Longfin Smelt larvae to SWP and CVP diversions.

As a result of the CESA listing, CDFW issued the California Department of Water Resources (DWR) an Incidental Take Permit (ITP) (CDFG 2009b), which permitted DWR to operate the SWP with some amount of incidental impact to Longfin Smelt. To account for the magnitude of larval Longfin Smelt entrainment at the SWP, CDFW estimated larval entrainment by coupling larval catch information collected from 1991-1994 and 2005 with outputs from a hydrodynamic model (CDFG 2009b). This approach involved some speculation as larval Longfin Smelt distribution data was limited and salvage data was unavailable for this lifestage. This method demonstrated that in some years, larval entrainment could be relatively high if distribution of Longfin Smelt extended into the southern portion of the Delta (CDFG 2009b).

Pursuant to CESA, the ITP required DWR to avoid, minimize, and fully mitigate all impacts to Longfin Smelt due to operations of the SWP. Specifically, minimization of Longfin Smelt entrainment at the SWP diversions is achieved, in part, by managing water exports in real-time. This strategy relies on empirical negative relationships between Old and Middle river flows, fish distribution, and salvage (CDFG 2009b; Grimaldo et al. 2009). However, larval Longfin Smelt salvage and distribution data did not exist at the time, and without this information it would be difficult to minimize entrainment of larval Longfin Smelt in the winter and early spring (January-March). To partly address this issue, CDFW developed and implemented a new monitoring program in 2009, the Smelt Larva Survey (SLS), to monitor early-post hatch larval Longfin Smelt distribution between January and March across the Delta, Suisun Bay, and Suisun Marsh.

Unlike most other long-term monitoring programs of the Estuary, the SLS was explicitly designed to provide resource agency managers with real-time distribution information for weekly assessments of larval Longfin Smelt entrainment risk into the SWP. To best manage entrainment impacts on Longfin Smelt larva, resource managers utilized the SLS as a means of detecting uncommon but important distribution events. This required biologists to implement the SLS and then disseminate the data in real-time and determine if actions were needed to minimize the entrainment of Longfin Smelt larva (CDFG 2009b). Data collected by the SLS would affect operations of the SWP through distribution and density criteria identified within the ITP, or through expert opinion (CDFG 2009b). Because of this explicit need, the SLS does not sample the geographic extent of Longfin Smelt spawning within the Estuary, and instead focuses on distribution information east of San Pablo Bay.

Here I take an opportunity to analyze data collected by the SLS since 2009, and ask specific questions related to the distribution and abundance of post-hatch larval Longfin Smelt within the Upper Estuary.

1. Has the abundance of larval Longfin Smelt changed since 2009 within the Upper Estuary?

2. Did previously described regional differences in distribution of Longfin Smelt in the Upper Estuary persist? 


\section{METHODS}

\section{Study Area}

The San Francisco Estuary is where freshwater flows from California's Central Valley watersheds meet the landward influence of the Pacific Ocean. The Estuary is one of the largest estuaries on the west coast of the United States and consists of large, tidally influenced waterways which vary in salinity based on freshwater inflows. Here, following the spatial sampling grid of the SLS, I delineate the upper, eastward region of the Estuary as the waters east of, and including, Carquinez Straight (Fig. 1). The Upper Estuary consists of two major regions: (1) the Delta, which is mostly riverine channels lined with armored levees designed to hold back water and manage flood risk, and (2) Suisun Bay, which is the area between the Delta and the Carquinez Strait. Suisun Bay consists of large bays of mostly open water with tidal marshes and managed wetlands. Suisun Bay is comprised of Grizzly and Honker bays as well as Suisun Marsh on its northern side. Low salinity habitat typically occurs within Suisun Bay and is an important feature of nursery habitat for native fish species (Meng and Matern 2001; Hobbs et al. 2006).

The Delta is where the two major drainage basins of California's Central Valley converge to eventually flow into the Pacific Ocean. The Sacramento River enters the Delta from the northeast and provides most of the freshwater inflow, while the San Joaquin River enters from the southeast. The CVP and SWP water export facilities are located on the most southern end of the Delta and export water directly from distributaries of the San Joaquin River.

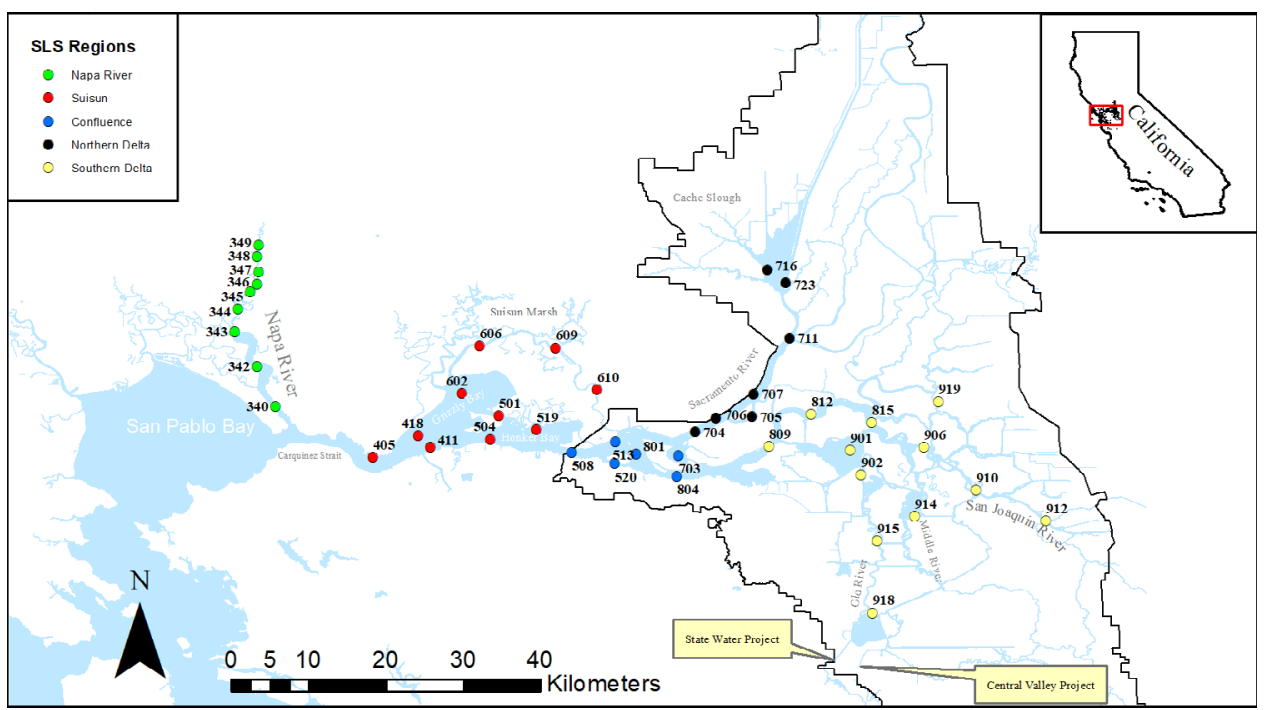

Figure 1. The geographic extent of the SLS sampling grid in San Fransisco Estuary, deliniated into five sub regions: Napa River, Suisun, Conflence, Northern Delta, Southern Delta. Colored circles represent the geographic location of 44 survey stations associated with the Smelt Larva Survey. Black solid line represents the Legal Delta boundary 
To compare distribution patterns of larval Longfin Smelt across the study area, I delineated the SLS sampling grid into five sub regions. These sub regions were based on a combination of ITP criteria, the legal Delta as defined by the Delta Protection Act, and general geography. (1) the Southern Delta region includes the 12 station entrainment criteria described in the ITP (CDFG 2009b) and geographically encompasses the San Joaquin River and its distributaries within the Delta. (2) the Northern Delta region includes seven SLS stations on the Sacramento River and Cache Slough which are upstream of the geographic confluence with the San Joaquin River. (3) the Confluence region is the geographic location of where the Sacramento and San Joaquin Rivers converge within the Delta and includes the remaining stations within the legal Delta boundary. (4) The Suisun region includes stations within Suisun Marsh, Grizzly Bay, and Honker Bay. (5) the Napa River region includes all stations within the Napa River (Fig. 1).

\section{Monitoring Data}

For this analysis, I utilized data collected from two long-term monitoring programs: The Fall Midwater Trawl (FMWT) and the SLS. The FMWT started in 1967 with the purpose of monitoring the effects of water exports on the relative abundance and distribution of age- 0 Striped Bass (Stevens 1977). However, the FMWT also collected data on other, predominantly pelagic, species and has since become important in monitoring long-term trends in relative abundance for some of the native species of the Estuary, including Longfin Smelt (CDFG 2009b; Nobriga and Rosenfield 2016; Eakin et al. 2020). Because Longfin Smelt typically spawns in its second year of life, I use the $\mathrm{FMWT}_{n-2}$ indices of relative abundance calculated from all ages of Longfin Smelt collected in the fall from 2007 through 2017 to provide a reference to relative spawning stock size for each year $n$ (Table 1).

The SLS was included as part of the broader Interagency Ecological Program ${ }^{3}$ (IEP) - a multi-agency science consortium - and is one of several fish monitoring programs implemented by IEP within the Estuary. The SLS samples bi-weekly between January and March at 44 stations across the Upper Estuary and the Napa River, obliquely towing a fixed frame sled with skis for a single 10 -minute tow. The $505 \mu \mathrm{m}$ mesh net has a $0.37 \mathrm{~m}^{2}$ mouth area opening and is most effective at catching newly hatched Longfin Smelt $(\leq 10 \mathrm{~mm}$ fork length; Grimaldo et al. 2017). Data used for this analysis were collected by the SLS from 2009-2019. These data are publicly available through CDFW (IEP 2020).

As previously described, the SLS monitoring program was developed and implemented to provide real-time distribution information to agency managers regarding larval Longfin Smelt entrainment risk. Since its implementation in 2009, some changes have occurred to the SLS. First, the inaugural year of the SLS had only five surveys occurring from January-March. By 2010, the SLS was expanded in its temporal range to include a sixth survey and has conducted six surveys per season since. Second, as part of an agreement with SWP stakeholders, the SLS was expanded into the Napa River in 2014. The purpose for this expansion was to test hypotheses related to production of Longfin Smelt in smaller tributaries of the Estuary relative to production of Longfin Smelt within the Delta and Suisun. Napa River sampling ceased at the end of the 2018 sampling season due to a combination of funding and closing of the agreement.

The 2009 ITP concluded that the position of the low salinity zone within the Estuary would relatively predict the extent of adult Longfin Smelt spawning migrations into

\footnotetext{
${ }^{3}$ https://iep.ca.gov/
} 
Table 1. Relative abundance of Longfin smelt and water year indices for the Sacramento and San Joaquin Rivers for each year of the Smelt Larva Survey. Fall Midwater Trawl abundance represents the relative size of the adult Longfin Smelt spawning stock in the Estuary each year.

\begin{tabular}{cccc}
\hline Year & Previous FMWT & & \\
\hline 2009 & 13 & Sacramento Valley Index & San Joaquin Valley Index \\
2010 & 139 & Dry & Below Normal \\
2011 & 65 & Below Normal & Above Normal \\
2012 & 191 & Wet & Wet \\
2013 & 477 & Below Normal & Dry \\
2014 & 61 & Dry & Dry \\
2015 & 164 & Critically Dry & Critically Dry \\
2016 & 16 & Critically Dry & Critically Dry \\
2017 & 4 & Below Normal & Dry \\
2018 & 7 & Wet & Wet \\
2019 & 141 & Below Normal & Below Normal \\
\hline
\end{tabular}

a The FMWT index occurring from the fall two years prior to the start of the SLS each year.

the Delta during the winter (CDFG 2009b). Essentially, adult Longfin Smelt are going farther into the Delta when its dry and salinity moves further inland compared to when its wet and salinity is further west. To investigate this, I used water year indices developed by DWR which are based on water storage volume in the upstream reservoirs and measured snowpack $^{4}$. Water years are defined as the period between 1 October and the following 30 September to avoid splitting California's wet season in two as use of a calendar year would. Water year classifications do not provide explicit flow information for the winter, but rather, provide a binned evaluation of the hydrologic conditions experienced in each of these years. These water year classifications are derived for both the Sacramento and San Joaquin River basins separately. I relied on the Sacramento Valley Index to represent the water year due to its disproportionate contribution of freshwater to the Estuary. Indices can be one of five classifications: (1) Critically Dry, (2) Dry, (3) Below Normal, (4) Above Normal, and (5) Wet (Table 1).

\section{Data Analysis}

I calculated the Catch Per Unit of Effort (CPUE) for larval Longfin Smelt collected by the SLS, expressed as a relative density, to understand spatial and temporal trends of larval Longfin Smelt across the SLS sampling grid. To do this, I applied the following formula to each tow in the SLS across the entire time series ${ }^{5}$

$$
\mathrm{N}_{t}=\mathrm{F}_{t} / \mathrm{V}_{t}^{*} 1000
$$

\footnotetext{
${ }^{4}$ See https://cdec.water.ca.gov/reportapp/javareports?name=WSIHIST

${ }^{5}$ Established in the SLS metadata, see https://wildlife.ca.gov/Conservation/Delta/Smelt-Larva-Survey
} 
Where $\mathrm{N}_{t}$ represents the relative density of larvae per $1,000 \mathrm{~m}^{3}$ of water per tow $t, \mathrm{~F}_{t}$ is the number of larvae sampled per tow $t$, and $\mathrm{V}_{t}$ is the amount of water filtered through the net per tow $t$. To calculate the amount of water filtering through the net $\left(\mathrm{V}_{t}\right)$, I applied the following formula

$$
\mathrm{V}_{t}=\mathrm{A} * \mathrm{~K} * \mathrm{D}_{t}
$$

Where $\mathrm{A}$ is the net mouth opening in $\mathrm{m}^{3}, \mathrm{D}_{t}$ is the difference in the flowmeter reading from start to finish of each tow $t$, and $\mathrm{K}$ is the calibration factor for the flowmeter used to measure flow in the SLS monitoring program. To understand patterns in density through time, I calculated average CPUE for each station within each year, rounding up to the nearest whole fish. I will refer to this average as the per-station averaged density (PSAD) throughout the rest of this analysis. These PSAD were then plotted for all 44 stations from 2009-2019 simultaneously as a heat map, delineated by region, to visually compare trends through time.

Lastly, to investigate changes in presence over time, I applied an approach described in (Merz et al. 2011; Merz et al. 2013) and calculated a detection frequency for each station across all years to capture variation in larval Longfin Smelt detection by station and region within the SLS. The detection frequency was calculated by applying the following equation:

$$
\mathrm{P}_{s y}=\mathrm{S}_{s y} / \mathrm{T}_{s y} * 100
$$

Where $\mathrm{P}_{s y}$ is the proportion of tows where larval Longfin Smelt were detected by station $s$ per year $y, \mathrm{~S}_{s y}$ is the number of tows where larval Longfin Smelt were detected at station $s$ per year $y$, and $\mathrm{T}_{s y}$ is the total number of tows conducted at station $s$ per year $y$. To understand the relationship between CPUE and frequency of detection within the SLS, I used the R statistical software to calculate a Spearman's correlation coefficient between the two variables.

\section{RESULTS}

\section{Per-Station Averaged Density}

There were 2,463 SLS tows across the 44 monitoring stations in the Estuary, with a median tow volume of $185.452 \mathrm{~m}^{3}$. Longfin Smelt were collected in $60 \%(1,484)$ of SLS tows, resulting in a total of 78,955 Longfin Smelt. Of those fish, $246(<1 \%)$ were collected in the Napa River region, 37,540 (48\%) in the Suisun region, 21,818 (28\%) in the Confluence region, 16,011 (20\%) in the Northern Delta region, and 3,340 (4.3\%) in the Southern Delta region. Relative densities of larval Longfin Smelt varied through time across all five regions, declining towards the end of the time series. PSAD were lowest in the Napa River and Southern Delta regions, with median PSAD of 4 fish per 1,000 $\mathrm{m}^{3}$ and 3 fish per 1,000 $\mathrm{m}^{3}$ respectively. Of the five regions, PSAD were highest in the Confluence region, with a median PSAD of 152 fish per 1,000 $\mathrm{m}^{3}$. Peak densities occurred in 2013, with a median PSAD of 274 fish per 1,000 $\mathrm{m}^{3}$ across all regions. In contrast, 2017 had the lowest densities across the time series with a median PSAD of 1 fish per 1,000 $\mathrm{m}^{3}$ across all regions. PSAD sharply declined starting in 2014, with median PSAD ranging from 154 to 274 fish per $1,000 \mathrm{~m}^{3}$ between 2009 to 2013 to median PSAD of 1 to 65 fish per $1,000 \mathrm{~m}^{3}$ between 2014 and 2019 (Fig. 2). The Spearman's correlation coefficient between PSAD and detection frequency showed a strong positive correlation, with a $r_{s}=0.8962383$ (Fig. 4). 


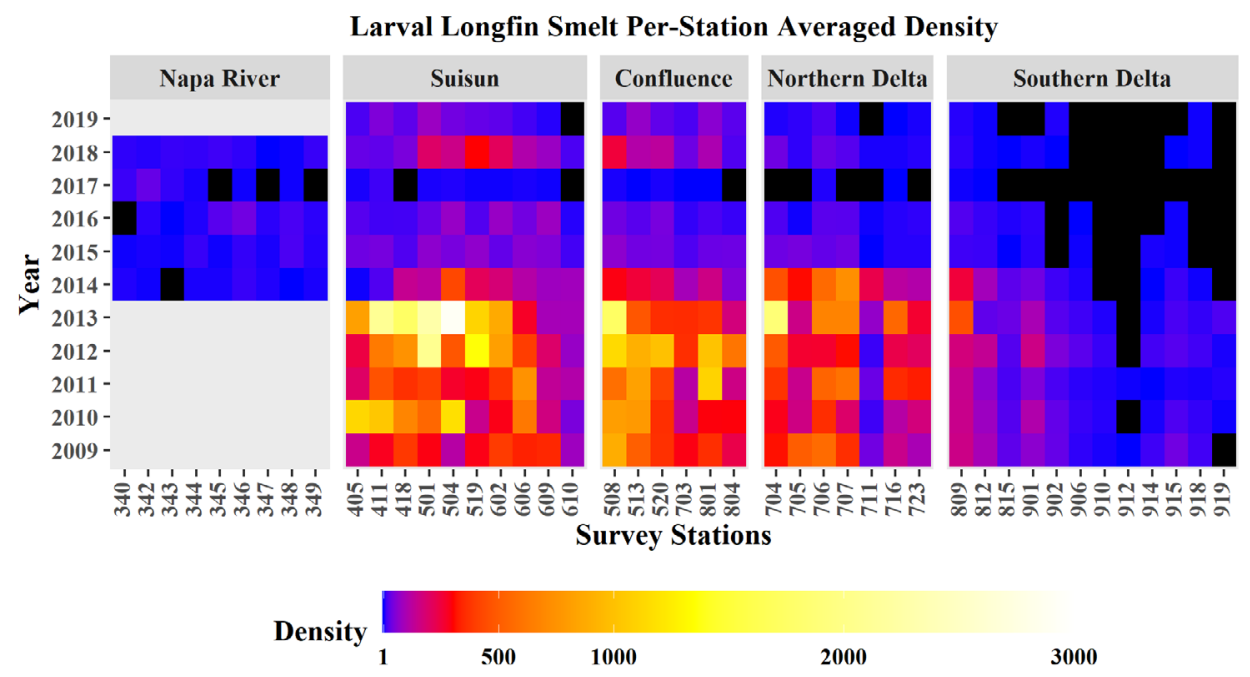

Figure 2. Per-station averaged densities for larval Longfin Smelt across four regions of the Upper Estuary. Densities were averaged at each station for each year of the Smelt Larva Survey. Legend presents average densities per 1,000 $\mathrm{m}^{3}$. Black boxes represent sampling stations which did not detect Longfin Smelt across all tows for that year.

\section{Frequency of Detection}

Longfin Smelt larva were detected in all 5 regions, however the frequency of these detections decreased through time (Fig. 3). In the Suisun region, detection frequency was highest in the early part of the time series, when fish were detected throughout the entire sampling period. Median detection frequencies were 100\% from 2009 through 2014, but became more variable in recent years. Detection frequencies in the Confluence region followed a similar pattern to the Suisun region, where median detection frequencies ranged from $83.33 \%$ to $100 \%$ from 2009 through 2015 but declined in recent years. In contrast to the Suisun and Confluence regions, detection frequency in the Northern and Southern Delta regions was more variable throughout the time series, but still showed a similar decline through time. Median detection frequencies in the Northern Delta were 100\% in 2009 and 2010 and reached a low of $0 \%$ in 2017. In the Southern Delta region, detection frequencies were highest in 2009 and 2010 with median frequencies of $80 \%$ and $83.33 \%$ respectively, however, detection frequencies in the latter part of the time series are the lowest of all regions, with median detection frequencies ranging from 0\% to 33.33\% from 2014 to 2019 . Median detection frequencies in the Napa River region ranged from $16.67 \%$ to $50 \%$ for all years sampled.

\section{DISCUSSION}

Understanding life stage specific trends in distribution and abundance through time is important for managing a rare species. For Longfin Smelt, understanding the density and distribution of larvae into the the southern portions of the Delta has been parmount for minimizing entrainment impacts in real-time. Because of this, a relatively new long-term monitoring program was created, the SLS, with a specific purpose of being used as tool 


\section{Frequency of Detection by Station}
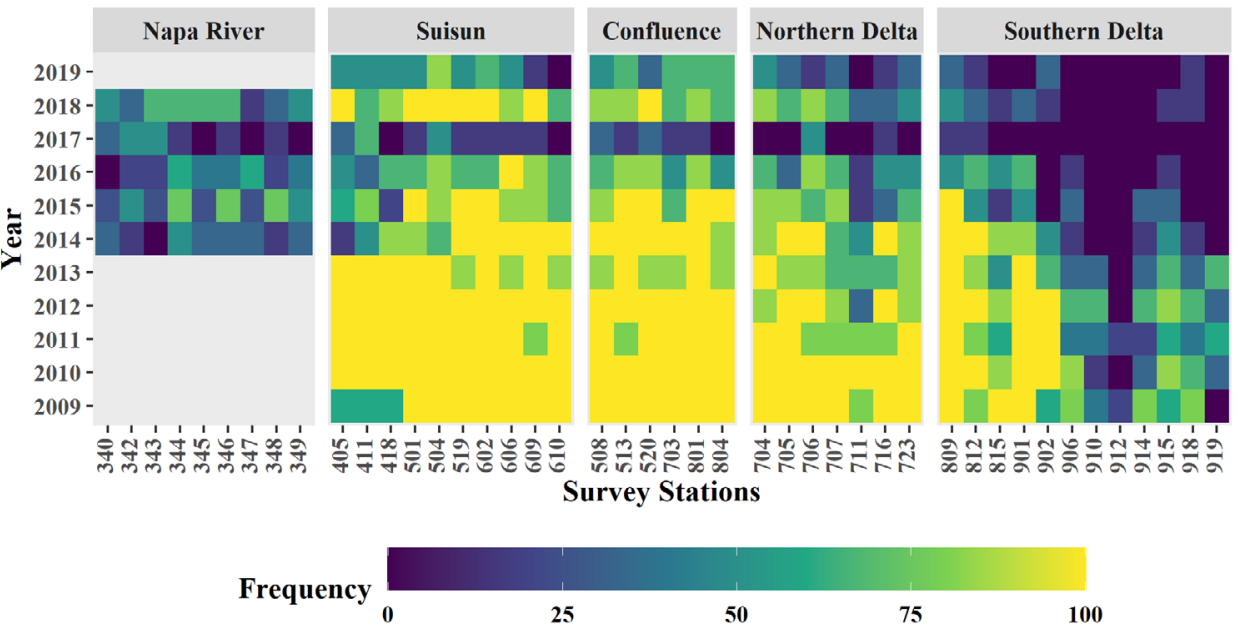

Figure 3. Frequency of larval Longfin Smelt detection by station across four regions of the Upper Estuary. The number of tows where larval longfin smelt were collected over the total number of tows conducted at a given station per year. Legend represents percent frequencies of detection from $0-100 \%$.

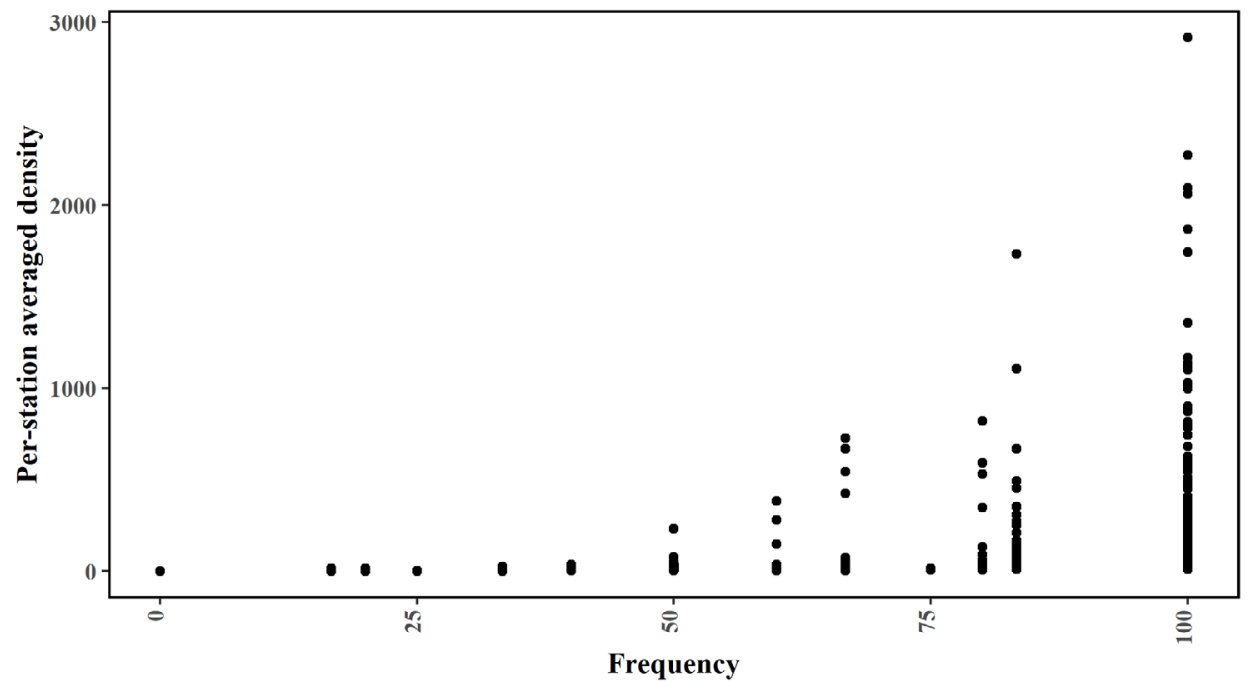

Figure 4. Scatterplot of per-station averaged density on the y axis, expressed as fish per $1,000 \mathrm{~m}^{3}$. X-axis represents frequencies of detection from $0-100 \%$.

for implementation of the 2009 ITP. However, I've shown here that this data provides important information which resource managers can also use to furthur the comprehensive understanding of the species within the Estuary. 


\section{Estuary-Wide Change}

My analysis displayed an abrupt change in larval densities across all stations and regions in the Upper Estuary, except for the Napa River. This abrupt change started in 2014 and persisted through 2019. Densities in the Napa River were already low when sampling began in 2014, and stayed consistently low until sampling ended in 2018. This trend follows a continuing decline of the species and has been observed since monitoring began several decades ago (Rosenfield and Baxter 2007; Thomson et al. 2010; Nobriga and Rosenfield 2016). These changes coincide with a recent drought that started in 2012 and lasted through 2016 (Lund et al. 2018). Given the continued decline combined with the expectation that droughts would negatively impact native species of the Estuary, low densities would be expected across the Estuary until conditions improved. Spawning stock abundance also hit record lows during this time, and a combination of dry conditions and low abundance is the most likely explanation for the patterns observed within the data. However, there are other pieces of evidence that also explain some patterns in the density and distribution of larval Longfin Smelt observed in the SLS. For example, young of the year Longfin Smelt aggregate within and around the low salinity zone (Dege and Brown 2004), which is commonly located in the Suisun and Confluence regions during the winter in most years. The mechanisim behind the aggregation of young of the year Longfin Smelt in the low salinity zone has two prevailing hypotheses: (1) Longfin Smelt are transported down stream by freshwater flows and are then retained in the low salinity habitat, or (2) Longfin Smelt are hatching in or near the low salinity zone and are locally dipsersed by tidal forces, as demonstrated in a particle tracking simulation by Kimerer et al. (2014). Data collected by the SLS may illucidate these mechanisims by providing data on newly-hatched Longfin Smelt, and one of the next steps in analzing this data should be the use of quantitaive models to investigate the distribution of recently hatched Longfin Smelt and their relationship with salinity to determine if aggregation within the low salinity zone is due to transport, local hatching, or a combination of both. Expansion of the SLS into portions of the Lower Estuary would also provide data that could inform how transport mechanisims affect larval distribution within the Estuary.

Relative abundance of longfin smelt in the fall was variable through this period, with the lowest FMWT index occurring in the fall of 2015. Longfin Smelt abundance is known to be positively influenced by the magnitude of freshwater flows exiting the Delta (Jassby et al. 1995; Kimmerer 2002; Kimmerer et. al 2009). Therefore, prolonged dry periods are expeted to negatively impact relative abundance, while wetter years are expected to positively impact relative abundance. The high flows observed in 2017, one of the wettest years on record, contributed to a moderate increase in relative abundance from the previous year. However, increases in larval densities which were observed in the Suisun and Confluence areas in 2019 were still lower than those observed prior to the 2014 decline. In particular, larval densities in the Northern Delta region decreased by up to two orders of magnitude, and 2019 data from this region showed relatively little change in density in response to the moderate increase in spawning stock abundance from 2017.

\section{Regional Distribution}

My findings show that prior to 2014, larval Longfin Smelt were consistently detected at nearly every station across all regions except the Southern Delta. Adding to previous descriptions of Longfin Smelt distribution, this data suggests that spawning within the 
Southern Delta may be more consistent and widespread than previously described in 2009 (CDFG 2009a). However, densities observed in this region remain relatively low and are largely driven by catches at stations along the eastern portion of the San Joaquin River.

The Southern Delta region is an important area for California's water conveyance and infrastructure system as this is where feshwater is exported from the Delta. Longfin Smelt larvae can occur in the Southern Delta as a result of multiple processes: 1) voluntary movement to spawning habitat by adults resulting in hatching in the region, 2) entrainment into the region via hydrodynamic processes, or 3) a combination of both (CDFG 2009b). The data presented here demonstrates that Longfin Smelt are spawning in the Southern Delta. This is consistent with historical descriptions of adult Longfin Smelt presence in portions of the lower San Joaquin River (CDFG 2009a; Merz et al. 2013; Rosenfield 2010). However, my findings show that detection of Longfin Smelt larva in the SLS is positively correlated to relative larval densities at a given sampling location. Due to this correlation, resource managers may face challenges when attempting to discern a Southern Delta distribution of Longfin Smelt when abundance is low. This may result in a higher reliance on expert opinion to adequately minimize entrainment impacts to larvae under such circumstances.

\section{Napa River Production}

Recently, the Napa River has been shown to be a potentially important spawning area for Longfin Smelt in some years (Lewis et al. 2019). Contributions of larval Longfin Smelt from San Fransisco Bay tributaries were hypothesized to be substantially higher in wetter years (CDFW 2014) which was posited as an explanation for increases in Longfin Smelt abundance following a wet winter and spring period. SLS data collected from the Napa River shows that detection of Longfin Smelt is inconsistent, and when detected, Longfin Smelt densities were typically low when compared to areas east of the Napa River. Importantly, when densities in the Upper Estuary increased following the drought (2014-2016), catches in the Napa River stayed consistently low. This data indicates that the importance of the Napa River regarding Longfin Smelt production is relatively low when compared to portions of the Delta and Suisun, even under wet conditions such as those experienced in 2017. However, 2017 is the only wet year where the SLS sampled the Napa River, and this data may not represent a more typical wet year. For example, Lewis et al. (2019) were able to collect larvae on the Napa River for 2019 and although they used a different net, they did show substantially higher densities of larvae in the Napa River in 2019, a wet year not sampled by the SLS.

\section{Conclusion}

Newly developed monitoring programs can provide important information regarding data gaps for a rare species. Here I evaluated how a long-term monitoring program, which was launched in response to the listing of a species under CESA, has provided some useful insight into larval Longfin Smelt densities over time, but remains consistent with previous descriptions of Longfin Smelt spawning within the Estuary. Data presented in this analysis is helpful in understanding the current distribution and abundnce of young of the year Longfin Smelt within the Upper Estuary, but requires more sampling in the Lower Estuary as well as regular sampling of the Napa River to better understand the relationship that larval Longfin Smelt have with fresh water flows. The SLS data also demonstrates that distribution in the 
Upper Estuary can be extensive during wet years, as was observed in 2011. Next steps should focus on investigating changes in habitat conditions in these regional areas, specifically changes in spawning and rearing habitat for Longfin Smelt eggs and larvae and how those affect detection within the SLS. Additonally, there is a need to further investigate the interaction between larval Longfin Smelt distribution and hydrodynamic processes of the Estuary, which include entrainment into and within the Southern Delta region. Lastly, there is a need to sample a broader area to capture the full extent of larval Longfin Smelt distribution within the Estuary, specifically expanding sampling into the Lower Estuary, such as San Pablo Bay and San Fransisco Bay. A broader sampling area will provide a more complete understanding of the importance the Upper Estuary has in the production of Longfin Smelt each year.

\section{LITERATURE CITED}

Baxter, R. D. 1999. Osmeridae. Pages 179-216 in J. Orsi, editor. Report on the 1980-1995 fish, shrimp, and crab sampling in the San Francisco Estuary, California. Interagency Ecological Program for the Sacramento-San Joaquin Estuary Technical Report No. 63.

Brown, R., S. Greene, P. Coulston, and S. Barrow .1996. An evaluation of the effectiveness of fish salvage operations at the intake to the California aqueduct, 1979-1993. Pages 497-518 in J. Hollibaugh, editor. Seventy-Fifth Annual Meeting of the Pacific Division/American Association for the Advancement of Science, June 19-24 1994, San Francisco, CA, USA.

Castillo, G., J. Morinaka, J. Lindberg, R. Fujimura, B. Baskerville-Bridges, J. Hobbs, G. Tigan, and L. Ellison. 2012. Pre-screen loss and fish facility efficiency for Delta smelt an the south Delta's state water project, California. San Francisco Estuary \& Watershed Science 10(4):art4.

California Department of Fish and Game (CDFG). 2009a. A status review of the longfin smelt (Spirinchus thaleicthys) in California. Bay Delta Office, Yountville, CA, USA.

California Department of Fish and Game (CDFG). 2009b. California Endangered Species Act Incidental Take Permit No. 2081-2009-001-03, California Department of Fish and Wildlife, Bay Delta Region (CDFW), Yountville, CA. Available from: http://www.dfg.ca.gov/delta/data/longfinsmelt/documents/ITP-Longfin-1a.pdf (Accessed 5 July 2016)

California Department of Fish and Wildlife (CDFW). 2014. Longfin Smelt Study Plan: field, laboratory, and data analyses to investigate the distribution and abundance of Longfin Smelt in the San-Francisco Estuary. Fisheries Branch, Sacramento, CA, USA.

Dege, M., and L. Brown. 2004. Effect of outflow on spring and summertime distributions and abundance of larval and juvenile fishes in the upper San Francisco estuary. Pages 49-65 in F. Feyrer, L. Brown, R. Brown, and J. Orsi, editors. American Fisheries Society Symposium 39, August 20-23 2003, Santa Cruz, CA, USA.

Eakin, M., R. Baxter, J. Hobbs, T. Ngyuen, F. La Luz, T. Tempel, L. Damon, S. Anwar, A. Allison, and B. Jacobs. 2020. Attachment 7: State Water Project effects on Longfin Smelt and Delta Smelt. IState Water Project 2020 Incidental Take Permit No. 2081-2019-066-00. California Department of Fish and Wildlife, Water Branch, 
West Sacramento, CA, USA.

Grimaldo, L., T. Sommer, N. Van Ark, G. Jones, E. Holland, P. Moyle, B. Herbold, and P. Smith. 2009. Factors affecting fish entrainment into massive water diversions in a tidal freshwater estuary: can fish losses be managed? North American Journal of Fisheries Management 29:1253-1270.

Grimaldo, L., F. Feyrer, J. Burns, and D. Maniscalco. 2017. Sampling uncharted waters: examining rearing habitat of larval longfin smelt (Spirinchus thaleichthys) in the upper San Francisco Estuary. Estuaries and Coasts 40(6):1771-1784.

Hobbs, J., W. Bennet, and J. Burton. 2006. Assessing nursery habitat quality for native smelts (Osmeridae) in the low-salinity zone of the San Francisco Estuary. Journal of Fish Biology 69:907-922.

Interagency Ecological Program (IEP), L. Damon, T. Temple, and A. Chorazyczewski. 2020. Interagency Ecological Program San Francisco Estuary Smelt Larva Survey 2009-2020, version 3. Environmental Data Initiative. Available from: https:// doi.org/10.6073/pasta/696749029898fef9ad268435bee54d3d.

Jassby, A., W. Kimmerer, S. Monismith, C. Armor, J. Cloern, T. Powell, J. Schubel, and T. Vendlinski. 1995. Isohaline position as a habitat indicator for estuarine populations. Ecological Applications 5:272-289.

Kimmerer, W. 2008. Losses of Sacramento River Chinook salmon and Delta smelt to entertainment in water diversions in the Sacramento-San Joaquin Delta. San Francisco Estuary \& Watershed Science 6(2):art2.

Kimmerer, W., E. Gross, and M. MacWilliams. 2009. Is the response of estuarine nekton to freshwater flow in the San Francisco Estuary explained by variation in habitat volume? Estuaries and Coasts. 32:375-389.

Kimmerer, W., and M. Nobriga. 2008. Investigating particle transport and fate in the Sacramento-San Joaquin Delta using a particle tracking model. San Francisco Estuary \& Watershed Science 6(1):art4.

Kimmerer, W. J. 2002. Effects of freshwater flow on abundance of estuarine organisms: physical effects or trophic linkages? Marine Ecology Progress Series 243:39-55.

Lund, J., J. Medellin Azuara, J. Durand, and K. Stone. 2018. Lessons from California's 2012-2016 drought. Water Resources Planning and Management 144(10):13.

Lewis, L., A. Barros, M. Willmes, C. Denney, C. Parker, M. Bisson, J. Hobbs, A. Finger, G. Auringer, and A. Benjamin. 2019. Distribution of adult, larval, and juvenile Longfin Smelt in tributaries and marshes of the San Francisco Estuary. University of California, Davis, Department of Wildlife, Fish and Conservation Biology, Davis, CA, USA.

Meng, L., and S. A. Matern. 2001. Native and introduced larval fishes of Suisun Marsh, California: the effects of freshwater flow. Transactions of the American Fisheries Society 130:750-765.

Merz, J. E., S. Hamilton, P. S. Bergman, and B. Cavallo. 2011. Spatial perspective for Delta smelt: a summary of contemporary survey data. California Fish and Game 97:164-189.

Merz, J. E., P. Bergman, J. Melgo, and S. Hamilton. 2013. Longfin Smelt: spatial dynamics and ontogeny in the San Francisco Estuary, California. California Fish and Game 99:122-148.

Monsen, N. E., J. Cloern, and J. Burau. 2007. Effects of flow diversions on water and habitat quality: examples from californias highly manipulated Sacramento-San 
Joaquin Delta. San Francisco Estuary and Watershed Science 5(5):art2.

Morinaka, J. 2013a. A history of the operational and structural changes to the John E. Skinner fish protective facility from 1968 to 2010. Interagency Ecological Program for the San Francisco Bay/Delta Estuary, Tehnical Report 85, Sacramento, CA, USA.

Morinaka, J. 2013b. Acute mortality and injury of Delta Smelt associated with collection, handling, transport, and release at the State Water Project fish salvage facility. Interagency Ecological Program for the San Francisco Bay/Delta Estuary, Technical Report. 89, Sacramento, CA, USA.

Moulton, L. L. 1974. Abundance, growth, and spawning of the longfin smelt in Lake Washington. Transactions of the American Fisheries Society 103:46-52.

Nobriga, M., and J. Rosenfield. 2016. Population dynamics of an estuarine forage fish: disaggregating forces driving long-term decline of longfin smelt in California's San Francisco Estuary. Transactions of the American Fisheries Society 145:44-58.

Reyes, R., J. Morinaka, and B. B. Bridges. 2018. A history of the operational and structural changes to the Tracy Fish Collection Facility. Interagency Ecological Program for the San Francisco Bay/Delta Estuary, Sacramento, CA, USA.

Rosenfield, J., and R. Baxter. 2007. Population dynamics and distribution patterns of longfin smelt in the San Francisco Estuary. Transactions of the American Fisheries Society 136:1577-1592.

Rosenfield, J. 2010. Life history conceptual model and sub-models for longfin smelt, San Francisco Estuary population. Report submitted to the Sacramento-San Joaquin Delta Regional Ecosystem Restoration Implementation Plan, Sacramento, CA, USA.

Stevens, D. E. 1977. Striped Bass (Morone saxatilis) year class strength in relation to river flow in the Sacramento-San Joaquin Estuary, California. Transactions of the American Fisheries Society 106:34-42.

Thomson, J. R., W. J. Kimmerer, L. R. Brown, K. B. Newman, N. Ralph Mac, A. B. William, F. Frederick, and F. Erica. 2010. Bayesian change point analysis of abundance trends for pelagic fishes in the upper San Francisco Estuary. Ecological Applications 20:1431-1448.

Submitted 15 December 2020

Accepted 21 January 2021

Associate Editor was M. Fish 